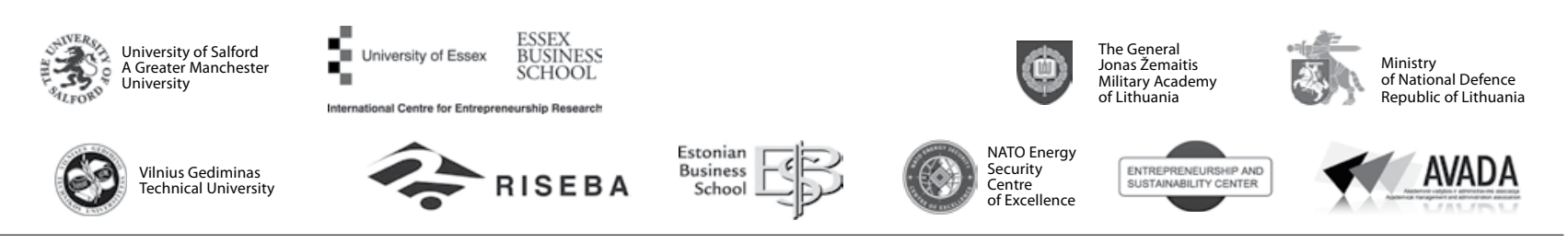

\author{
JOURNAL OF SECURITY AND SUSTAINABILITY ISSUES \\ ISSN 2029-7017 print/ISSN 2029-7025 online \\ 2017 June Volume 6 Number 4 \\ http://doi.org/10.9770/jssi.2017.6.4(7)
}

\title{
WORLD CHALLENGES AND ECONOMICS OF GEORGIA
}

\author{
Murman Kvaratskhelia \\ Iv. Javakhishvili's Tbilisi State University, Georgia, Tbilisi, University st. N1 \\ E-mail:murmankvara@rambler.ru
}

Received 20 November 2016; accepted 26 February 2017

\begin{abstract}
The phenomenon of globalization is wide, changeable and versatile. Therefore, there are a lot of different and contradictory opionins about its historical nature, driving motives and assessment of its influence on the various spheres of the social life. As it is widely known, globalization is the integrity of the processes having place in the world, inspiring people to acquire the common quality and character and draw near each other. The problem of its influence especially on the small countries doesn't lose its topicality even today. Facts, when after the global integration a country with a small and open economics improves its economic conditions and becomes active on the international stage, due to the development of the communication and education systems, is a reflection of the fact, that globalization has a positive impact on such countries and helps them not to lag behind the world progress.
\end{abstract}

Keywords: globalization, challenges, small countries.

Reference to this paper should be made as follows: Kvaratskhelia, M. 2017. World challenges and economics of Georgia, Journal of Security and Sustainability Issues, 6(4): 619-625 http://doi.org/10.9770/jssi.2017.6.4(7)

JEL codes: $\mathrm{O} 10$

\section{Introduction}

In the Western literature the core idea of determination of globalization is the fact that share of the deal made between the populations of different countries is growing rapidly (Grubicka.; Matuska 2015; Korsakienè et al. 2015; Razminienè, Tvaronavičienè 2017)

According to the definition given by the UN (World Invesment Report, 1997), globalization of economics means the process of formation of the corresponding organizational structures and movement of increasing flow of goods and service lying beyond the national borders, for appropriate management of the growing net of international economic deals.

According to Sh. Yusuf and J. Stiglitz globalization is a close integration with the increasing flow of trade, capital and ideas, as a result of formation of the international manufacture nets under the influence of the investment activities of the transnational corporations. (Yusuf, Stiglitz, 2000).

In R. Harris's (Harris, 1993) opinion globalization is the increasing internationalization of goods, service sphere, distribution and marketing. In modern political literature various researchers give to the globalization 
process different interpretations: Martin Albrow (Albrow, 1990) - globalization covers all the processes, which will turn people into the one, global society...English sociologist Anthony Giddens (Giddens, 2002) - It is intensification of the social relations, which connects the remote places in that way, when events are developed by the events taking place thousands of miles away and vice versa... German scientist Emanuel Richter (Richter, 2010) - It is a global net, which " soldered " earlier isolated and scattered societies to one interrelated world... American political expert Robert Cox - Globalization means internalization of the product, new international distribution of labor, new migration movement from the South to the North, new opposed environment, which speeds up all the processes and the last, internationalization of the state, making them trivial agents of the universe (Bayls,Smith,2001).

We think, this small circle of the scinetists will be enough, as in our opinion, this process, where the social ties are separated from the territoriality, georgraphy, so that the life of mankind goes on in one, integral, and inseparable space, when the national states and their sovereignty are covered by the transnational factors and subdue to it (Bek, 2001). Despite, globalists think that not a single state can lock itself in its shell and be able to separate from others, as the world society implies unity of social relations, not being defined by the national state policy. In my opinion, national state, national economics and culture or consciousness, are considered of the highest value. That's why we are to mitigate opposition and resistance and assign a specific meaning to the permanent efforts of our ancestors to maintain the nationhood.

\section{The Priorities of Country Existence}

One cannot imagine existence of a state without a national ideology and priorities. French Philosopher Destutt de Tracy (1754-1853) was the first to use the world "ideology" (De Tracy, 2008), as a science about the ideas, though in the $19^{\text {th }}$ century, Carl Marx considered ideology as the unity of the "ruling class", which implies division into classes and inevitability of exploitation. In the $20^{\text {th }}$ century, scientist of the liberal orientation presented ideology as means of social control, which was to guarantee social consent and submission, therefore fascism and communisms were regarded as two variants of the narrow thinking, not allowing the existence of the different opinion. On this background, liberalism, conservatism, and democratic socialism were perceived, as "open" systems, allowing and requesting free thinking, critics and opposition, but instead of ideology they chose pragmatism, tradition and history. Marx insisted that his ideas were of ideological and not scientific character. Liberals also refused to include their philosophy into the world ideology; as for conservatives they, even today are on the pragmatic and not ideological position in politics. That is the reason, why nowadays doesn't exist neutral and fully acceptable classification and therefore it is necessary to set it free from the idea, that ideology can be good or bad, lie or truth, liberating or subduing. We believe, that ideology can be explained, as the integrity of ideas, managing or approving political deeds in this or that form.

Simultaneously with extension of the process of globalization, ethnical nationalism flared up, which is blamed in brutal ethno conflicts creating the threat to the territorial integrity of the Nation -State, weakened them, resulting in the strengthening of opposition of the population against the State and evoked feeling of a new ethnical solidarity. People lost their orienting point and when the old habits and traditions were attacked, the Christian moral was practically erased from the sphere of actions and an unbelievable layer emerged from the depths, faceless, one integral unit, honest and dishonest at one and the same time.

A new type of moral was created. Bragging with the illegally grabbed reaches and unnatural segmentation of the society into the caste became an inspirational model. All the mentioned above prevents successful functioning of democracy.

\section{Globalization and Small Countries}

As it is widely known, globalization is the integrity of the processes having place in the world, inspiring people to acquire the common quality and character and draw near each other. The problem of its influence especially on the small countries doesn't lose its topicality even today. Facts, when after the global integration a country 
with a small and open economics improves its economic conditions and becomes active on the international stage, due to the development of the communication and education systems, is a reflection of the fact, that globalization has a positive impact on such countries and helps them not to lag behind the world progress. If such sort of country wants to claim a place on the international arena, it has to concentrate on the spheres, such as economis and education.

Globalization conditions the close connection of countries and countries with small and open economics have the chance of being included into the various global educational programs, e.g. the student exchange program „ERASMUS”+, being funded by the European Union, which gives to students from Georgia, Armenia and other countries a chance to study in the leading universities of Europe, which in its turn gives them the greatest experience for the future career progress.

Growth of the number of international governmental and grass-root organizations is the accompanying process of globalization. Existence of such organizations, are the guarantee of including of the many, small states in the significant programs and arrangements, which promotes peace in the world, helps develop humanism and enhance closeness of different cultures. One of the brilliant examples, is the peacemaking program of ISAF in Afghanistan, uniting 51 countries, among them those which are the members of NATO and those which are not members of NATO (Georgia as well). Within this program approximately 130000 military personnel took part and among them Georgian soldiers as well. The number of Georgian soldiers was quite large -885 according to the latest information. (NATO static assects, 2015).

Representatives of the school of realism come to the agreement, that " a small country from the militarypolitical point of view is weak and cannot make provision of its own national interests independently"(Rondeli 2006). Thus, involvement of the small states in the programs like ISAF guarantees contribution to the world peace, retraining of the human resources and process of development of the military technology; all this will increase the defense ability with the aim of national protection of national interests.

\section{Globalization Features}

Among the positive characteristic features of globalization, are present economic relations of the world and free trade phenomenon. Free trade enables different countries to produce goods and service for the markets without any issues. Taking into consideration the fact, that not a single country and especially the small one is able to create a full-fledge industrial complex, the support of various institutions or financial one is necessary to them. Namely, such kind of support from the multinational manufacturers and partner states, not to say anything about the adaptation to the global shifts worked wonders of the "small Singapore" - and due to the sound economic policy, its annual financial growth reached $7 \%$ according to the data of 2014 , which in reality is a great index (World Bank, 2015).

We mustn't forget Hong-Kong, which in 2011-2013 became the unit having the most globalized economics, being the first in the world rating in the categories of technological innovations and ideas, capital transactions and cultural exchange (SCMP, 2013).

In spite of the above mentioned positive influence, the general idea is, that globalization on the contrary, creates a threat to the small countries, as it is directed towards the uniformity and standardization of mode of life, which in its turn means revaluation of the national value orientation system. In reality, exploiting of the global process for their personal benefit will help the small countries to maintain their singularity and uniquiness and become popular. The best example is the organization for education, science and culture of UN (UNESCO), the main purpose of which is protection of the cultural heritage of the world and variety in the epoch of globalization. From the year of 2003 the organization ratified the convention (UNESCO, 2015), which guarantess protection of the non-material heritage of the member states ( among them Georgia, Armenia, Azerbaijan, Ghana, Djibouti and others), such as dances, songs, popular art, rituals, folklore, which together with the architectural monuments is an important part of the culture. 
It should be said, that globalization is an inconvertible process and is continuing its development. From approximation with the Western democratic spaces, small countries greatly benefit. Globalization, analyzed and viewed from the social -economic or the political aspect, is the best way of obtaining a competitive factor status in the international system (Travkina, 2015). According to Jan Scholte's explanation - "Globalization denotes the processes, with the help of which social relations are not prevented neither by distance nor by the borders" (Scholtte, Jan Aart, 2005). It is the indicator of trade and investments and increase of interrelation of the countries, free circulation of capital and formation of the common market. As for the rapid exchange of the modern management and marketing development, it enables small countries to become adequate members of the economically strong world. Globalization also ensures intense involvement of the representatives of small countries in the global training programs, working towards the increase of the number of the future qualified staff and the quality of service. It is a certain guarantee of security for small countries, as integration into the different transnational corporations or alliances often implies loyalty to the following principles: "One for all and all for one". As for the negative side of globalization - it is cultural assimilation, but preservation of cultural originality and its elements is the prerogative of the nation, its strength and clever policy. This will help a small country not to lose its identity in the global world, but to make a worthy input into the world heritage.

For the countries, which have small territory and are not densely populated integration with the global, international markets is essential. It enables a country, to extend further its physical borders and sell its production not only among its own numerically insignificant population.

\section{Globalization Index}

In the index of economic globalization the countries of high economics are not on the leading positions, though in the mentioned countries income per person is high. It can be explained, by the fact that for their economic development high level of globalization is not needed, as they have a vast inner market and inner capital of large value. At the same time, we would never find out a small country, where income per capita is high and simultaneously it has a low position according to the economic globalization index. International trade, foreign capital and labor force migration became a must for the development of small, natural resource poor countries.

According to the economic globalization Georgia occupies the $19^{\text {th }}$ place, but according to the level of globalization it is on the $63^{\text {th }}$ place. We have to stress the fact, that the index of globalization of the year of 2015 is based on the data of the year of 2012 .

According to the level of economic globalization Singapore holds the first place with 95.7 points (The highest point os 100). Ireland holds the second place with 92.6 points, on the third position is Luxembourg with 91.1 points. Then in the list come the countries having the developed economics. Georgia is on the $19^{\text {th }}$ place $(81$ points). The place of Georgia is paradoxical. According to the data of the year of 2014 average annual revenue per person in Georgia equals 3700 USD. In the given index before the $19^{\text {th }}$ place (Georgia) stands Mauritius with the lowest revenue of 105000 USD per person. Countries having income lower than Georgia occupy the place below the mark of 50 (World Bank, 2015).

$19^{\text {th }}$ place of Georgia was conditioned by the liberal policy of the international trade and possibility of the free inflow of the foreign capital. High position of Georgia is the reflection of the prospect of economic development and not of the achieved level of development.

A rapid increase in the index of globalization of Georgia started from the year of 2006, being a result of the reform of the years of 2004-2007. In the given years the foundation was laid to the present business environment of Georgia, which came through the war, economic crisis, political crisis and permanent Russian aggression. The above mentioned challenges were added to the problems existing in the sphere of court system and defense of the right on the private property. The development of Georgian economics on the background of the above mentioned problems is amazing and paradoxical; The truth is that, the growth of the economics of Georgia slowed down a bit in recent years (2013-2015), though in average it reaches the 4\% mark (Kakulia, 2016). 


\section{Globalization and economical risks}

In spite of the above mentioned, we have to mark, that the rapid globalization brought new threats, such as: nuclear contraband, transnational organized crime, cybercrime, trade of the organs of a human body, laundering of the money (Gasparėnienė et al., 2016; Teivāns-Treinovskis, Amosova, 2016; Samašonok et al., 2016; Kabát et al., 2017; Teivāns-Treinovskis et al., 2016; Apsītis et al., 2016).

The first publications about the new threats appeared in the 1980-ies; from the 1990-ies the dangerous results of the "nontraditional" threats manifested themselves in full. Traditionally, investigations and researches about the security matters were analyzed in connection with the national state, being considered the chief provider of the security. Civil society was presented as a passive object. Traditional concepts of security were concentrated on the geopolitics, military power, foreign policy of the national states. As for the civil society organizations, business and local organs of authorities were given an insignificant role.

In 1990, the Western political literature started to reconsider the traditional approaches of the security. In developed and developing countries, traditional threats are considered to be the problems in the economic growth, poverty and development and not the military blocks and their balance and super states. It conditioned widening of the concept of national security in two directions: the first, analyses of the interalation of the global, regional, local problems and second, putting emphasis on the relations between civil groups and people. Theoretically, widening of the conception of security complicated comprehension of the fact, what is the modern national security and what are its priorities in the new epoch after the end of the cold war.

Modern national security maintains shifting of the accents from the military security to the civil security. In this case, togethere with the state it involves civil organizations, as the providers of the security and implies different forms of struggle with the organized crime and corruption. In other words, struggle with the organized crime and corruption is the matter of the sphere of the security of the civil society. It should be mentioned, that together with the variability of the threats, the priorities of the security permanently change.

In conditions of the increasing globalization of the international economics, organized crime is one of the main "new" threats to the national and international economic security. Global organized crime obtains stronger impact on the international financial net and national economics and connection between them is also growing.

The fact, that criminals are able to find shelter in foreign countries and hide their illegal profit abroad impede work of the legal organs, as well as control of the financial flow, checking of the documentation and detaining of the perpetrators. A great part of the revenue from taxes doesn't replenish the budget of the national state due to the laundering of the money by the organized criminal groupings.

Fear towards the organized crime gives rise to the distrust, that democratic political institutions are able to cope successfully with the crime and political radicalism and gain the support of the strict, antidemocratic politics.

Experience of Sweden is interesting from the security point of view. Study of the experience of the civic security of Sweden and experience of cooperation between Scandinavian States and States of the Baltic region taking into account Russian threat, helped to better considering of the security challenges having place in Georgia and the region of the Caucasus. It was especially useful for analyzing why the security system was not effective in Georgia in settling the conflict with the Abkhazians and Ossetians and during the war of the year of 2008 with Russia (Kvaratskhelia 2011).

The system of civic security of Sweden, is based on the mild power policy, when the system of civic security of Georgia is based on the rigid power and was characterized by the traditional cold war time militarist approaches. In order for the increase of effectiveness of the security system of Georgia, more attention should be paid to the non-traditional approaches and turning back of a human being and society to the security, civil safety and stronger elements of the mild policy is today of a paramount importance. 


\section{Conclusions}

- National state, national economics and culture or consciousness, are considered of the highest value. That's why we are to mitigate opposition and resistance and assign a specific meaning to the permanent efforts of our ancestors to maintain the nationhood.

- Ideology can be explained, as the integrity of ideas, managing or approving political deeds in this or that form.

- Globalization, analyzed and viewed from the social -economic or the political aspect, is the best way of obtaining a competitive factor status in the international system.

- Preservation of cultural originality and its elements is the prerogative of the nation, its strength and clever policy. This will help a small country not to lose its identity in the global world, but to make a worthy input into the world heritage.

- In order for the increase of effectiveness of the security system of Georgia, more attention should be paid to the non - traditional approaches and turning back of a human being and society to the security, civil safety and stronger elements of the mild policy is today of a paramount importance.

\section{References}

Albrow, M. 1990 Globalization, know ledge an society https://books.google.lt/books?id=z7bWQCPZlLYC\&printsec=frontcover\&hl=1 $\mathrm{t} \&$ source $=\mathrm{gbs} \_\mathrm{ge} \_$summary_r\&cad $=0 \# \mathrm{v}=$ onepage $\& \mathrm{q} \& \mathrm{f}=\mathrm{false}$

Apsītis, A.; Joksts, J.; Antanavičienè, J. 2016. Threats to sustainable development: asset grabbing phenomenon and the legal concept of Force and Fear in Roman Law, Journal of Security and Sustainability Issues 6(2): 289-297. http://dx.doi.org/10.9770/jssi.2016.6.2(8)

Baylis and Smith, The Globalization of World Policits by John Baylis \& Steve Smith 2001 p. 2-12 http://www.kolegji-juridica.org/ new_web/wp-content/uploads/2017/04/The-Globalization-of-World-Policits-by-John-Baylis-Steve-Smith.pdf

Bek, L. 2001. Affairs pp. 27-31

Burduli, Vakhtang; Ramaz, Abesadze. 2013. Issue 7 "Sectoral, Technological and institutional-organization Structures OF The Georgian Economy: Development issues in the Context of Globalization". The Caucasus Globalization. p. 63

De Tracy, D. A treatise on political Economy, 2008

Erasmus+2015 “changing lives, opening lives”. Home page online. http://ec.europa.ua/programmes/erasmus-plus/index en.htm;

Gasparenienè, L.; Remeikienè, R.; Sadeckas, A.; Ginevičius, R. 2016. Level and sectors of digital shadow economy: the case of Lithuania, Entrepreneurship and Sustainability Issues 4(2): 183-197. http://dx.doi.org/10.9770/jesi.2016.4.2(6)

Giddens, Antony. 2002. Runaway world -how Globalization in Reshaping own lives https://books.google.lt/books?id=KPMtVIsNowC\&printsec $=$ frontcover\&dq $=$ Giddens,+ Anthony. $+2002 .+$ Runaway + world $+\%$ E2\% $\% 0 \% 93$ how + Globalization + is + Reshaping + own + li ves\&hl=lt\&sa=X\&ved=0ahUKEwj9ypKEh47UAhWFWCwKHRfOC5AQ6AEIJTAA\#v=onepage\&q\&f=false

Grubicka, J.; Matuska, E. 2015. Sustainable entrepreneurship in conditions of UN (Safety) and technological convergence, Entrepreneurship and Sustainability Issues 2(4): 188-197. http://dx.doi.org/10.9770/jesi.2015.2.4(2)

Harris R, G. Globalization, Trade, and Income, Canadian Journal of economics, November 1993, pp.775

Jandieri, G. 2006. "Globalization and Economics.” The Bulletin was commissioned by the Georgian Foundation for Strategic and International Studies.

Jaquet, Lois M.G. 1971 “The role of small states within Allience systems. "In small states in international relation.

Kabát, L.; Filip, S.; Filipová, L. 2017. Safety measurement peculiarities in selected countries, Journal of Security and Sustainability Issues 6(3): 343-356. http://dx.doi.org/10.9770/jssi.2017.6.3(2)

Kakulia N. 2016. The Characteristics of Transformation of Institutional Changes and Georgia. World academy of science, engineering and technology, conference proceedings. Berlin, Germany

Korsakienè, R.; Diskienė, D.; Smaliukienè, R. 2015. Institutional theory perspective and internationalization of firms. How institutional context influences internationalization of SMES?, Entrepreneurship and Sustainability Issues 2(3): 0-0. http://dx.doi.org/10.9770/ 
jesi.2014.2.3(3)

Kvaratskhelia, M. Problems of Post-Communist transformation, Georgia. The book "Network Society networked economy in Central and Estern Europe". Lublin (Poland) 2011

Nichols, Lucy, 1991. "Human resources and structural adjustment: evidence from Costa Rica", in Martin Godfrey (ed), skill Development for international Competitiveness.

Razminienė, K.; Tvaronavičiené, M. Clusters' role in globalization //CONTEMPORARY ISSUES IN BUSINESS, MANAGEMENT AND EDUCATION'2017 eISSN 2029-7963/eISBN 978-609-476-012-9 https://doi.org/10.3846/cbme.2017.028 p. 1-8

Rondelli, A. 2006. International Relations. Third edition. Tbilisi: Publishing house - "Nekeri"

Samašonok, K.; Išoraitė, M.; Leškienė-Hussey, B. 2016. The internet entrepreneurship: opportunities and problems, Entrepreneurship and Sustainability Issues 3(4): 329-349. http://dx.doi.org/10.9770/jesi.2016.3.4(3)

Scholte, Jan Aart. 2005. Globalization; A Globalization; A Critical Introduction. 2nd New York: palgrave Macmillan.

SCMP 2015 "Hond kong keeps top spot as most globalised economy". South China Morning post. Business page online. Int. http://www.scmp.com/busuness/economy/article/1158655/hong-kong-keeps-top-spot-most-globalised-economy;

Teivāns-Treinovskis, J.; Amosova, J. 2016. Some aspects of criminal environment impact on sustainable entrepreneurship activities, Entrepreneurship and Sustainability Issues 4(1): 17-24. http://dx.doi.org/10.9770/jesi.2016.4.1(2)

Teivāns-Treinovskis, J.; Amosova, J.; Načisčionis, J.; N̦esterova, M. 2016. Country’s development and safety: violent crimes in crime structure, Journal of Security and Sustainability Issues 6(2): 227-233. http://dx.doi.org/10.9770/jssi.2016.6.2(3)

Travkina, I. 2015. Export and GDP Growth in Lithuania: Short-run or Middle-run Causality?, Entrepreneurship and Sustainability Issues 3(1): 74-84. http://dx.doi.org/10.9770/jesi.2015.2.4(7)

UNESCO 2015. "Text of the Conversation of the safeguarding of the Intangible cultural Heritage", UNESCO online. Culture page online. http://www.unesco.org/culture/ich/en/convention;

World Bank, 2015. Singapore. http://data.worldbank.org/country/singapore;

World Investment Report, UNCTAD, 1977 pp.70

Yusuf Sh., Stiglits, J. Development Issues, Settled and Open, frontiers of development Economics, The Future in Perspective, World Bank, 2000, pp.235

Murman KVARATSKHELIA, Doctor of Economics and Professor, Iv. Javakhishvili's Tbilisi State University 